\title{
The hurdle of rhetoric: An analytical study of Omani students' translation of political speech
}

\author{
Susanne Ramadan Shunnaq \\ Sultan Qaboos University, Oman \\ Yarmouk University, Jordan
}

\section{Hassan Shuqair \\ Sultan Qaboos University \\ Oman}

\section{Adel Abu Radwan \\ Sultan Qaboos University \\ Oman}

Susanne Ramadan Shunnaq: Department of English, Faculty of Arts and Social Sciences, Sultan Qaboos University, Oman / Department of English, Faculty of Arts, Yarmouk University, Jordan.

| Correo electrónico: sxr30@hotmail.com

Hassan Shuqair: Department of English, Faculty of Arts and Social Sciences, Sultan Qaboos University, Oman.

| Correo electrónico: abufiras2003@hotmail.com

Adel Abu Radwan: Department of English, Faculty of Arts and Social Sciences, Sultan Qaboos University, Oman.

| Correo electrónico: radwan64@gmail.com 


\section{Abstract}

The present study explores the challenges Omani translation students at Sultan Qaboos University encounter in identifying schemes in American political discourse and rendering them accurately into Arabic. The research used data that was collected over two semesters between 2014-2016 and qualitatively analyses it. The study categorizes problem areas of incorrect or inaccurate student translations of rhetorical constructions and lists important findings which may encourage instructors of translation courses to reconsider their teaching methodologies.

Keywords: English-Arabic translation; political discourse; rhetorical devices; schemes; Sultan Qaboos University. 


\section{Introduction}

Political discourse draws heavily on rhetorical devices to achieve a host of communicative functions. Advancement in communication has nowadays made it relatively easy to scrutinize what politicians deliver. Therefore, it has become crucial for politicians to craft their political discourse carefully and write their speeches as effectively as possible for wide heterogeneous audiences. Since his election in 2009, president Obama's rhetorical style has attracted much attention and has led his addresses to be ranked among those with the most powerful communication strategies used by US presidents (Hernández-Guerra, 2012; Al-Ameedi, 2015). Obama, in contrast to some other contemporary presidential candidates and presidents, successfully used stylistic and rhetorical devices in his speeches to enhance his language and appeal to his audience for change, strengthen their convictions, address their concerns, and build his own ethos as a way to secure the trust and respect of a nation which majority had come to distrust the government under the Bush administration.

Since these devices are commonplace in political discourse, they cannot be ignored in translation courses. Students of translation who are also students of English as a foreign language often struggle when translating structures which contain rhetorical devices. These difficulties with the translation of rhetorical devices from English into Arabic have not yet found enough attention by researchers. Hence, this study investigates the student translators' ability to identify and translate rhetorical devices used in Obama's first inaugural speech into Arabic. Thirteen graduate students in the translation program at Sultan Qaboos University (SQU) were given the presidential speech in one of their courses to translate from English into Arabic. Their translations were qualitatively analyzed to identify the challenges they encountered in their translations. Accordingly, important conclusions were reached and recommendations given.

\section{Literature review}

One of the most challenging and interesting areas in translation is the translation of stylistic devices, mainly because their rendering into the target language reveals the skills of the translators and their cultural sensitivity. Translators are expected to make an effort to identify and preserve the stylistic devices of the source language text in the target language text. Sometimes, however, this becomes difficult or even impossible, as these devices may not be acceptable or available in the target language. Marzari (2006) points out, for example, that the syntactic and stylistic rules of the Greek language do not allow the use of asyndeton (50). In Greek, a structural unit cannot exist next to another one in a disconnected way. Arabic is similar in this respect as its syntactic and stylistic rules reject the idea of asyndetic coordination. Ibrahim, Aydelott \& Kassabgy (2000) assert that asyndeton is an impossible case in Arabic (102). Abdul-Raof (2001), however, cites examples of asyndeton or "the lack of conjunctions 
inter-sententially" in modern Arabic literature (139). These examples prove that writers have adopted asyndeton in Modern Standard Arabic (MSA) to create a similar aesthetic effect as can be achieved in English by the use of this rhetorical device, despite the fact that this is not native to the Arabic language and many would still believe that its use is unnatural.

In contrast, polysyndeton is not structurally the norm in modern English, though it is used frequently used as a rhetorical device. On the other hand, it is a norm in Arabic and as such is not conceived as a rhetorical device. Arabic uses coordinating conjunctions which connect words, phrases, and more complex structures; the most commonly used of which are wa, thumma, and auw (و) ثم, او (و), meaning and, then, or, respectively. Furthermore, the rhetorical style that aims at coordinating clauses or phrases to achieve semantic and stylistic parallelism and which is most evident in Arabic is parataxis. Khalil (2011) points out that, if authors intend to create a semantic or stylistic balance, they will conjoin phrases or clauses to achieve equal prominence (12). These paratactic constructions, however, do not exist in Arabic without coordinating conjunctions. Therefore, since parallel structures are quite common in Arabic (Johnstone, 1987), particularly in prose (Beeston, 1983: 180-85), antithesis, anaphora, and tricolon-all are rhetorical devices utilizing parallelism on the word, phrase, or sentence level-can be found.

Abdul-Raof (2006) considers antithesis as a semantic embellishment and discusses its different types (244-46). Antithesis cannot only be found in modern Arabic literature such as asyndeton, but reaches as far back in the history of Arabic as the Umayyad period (Meisami \& Starkey, 1998: 633, 659). Antithesis is a far more complex rhetorical device in both English and Arabic than asyndeton and polysyndeton or anaphora, for example. Thus, one expects that students have more problems with this device than with other simpler ones, which means that complexity of the structure is an issue.

Anaphora is another quite commonly used rhetorical device in English. Many orators, particularly political figures, have used and continue to use anaphora to achieve a powerful effect of force when delivering their speeches. In Arabic, the majority of available research on anaphora has been done in the context of pronominal reference expressions (Russell, 1984; Al-Haq, 1992; Abdellah, 2007; Al-Sabbagh \& Elghamry, 2007; Al-Mashkoor, 2014, amongst others). Although rhetorical repetition has been studied in literature, little attention has been paid to anaphora in translation studies. Dickins, Hervey \& Higgins (2002) dedicate a section of their book to grammatical and rhetorical anaphora where they explain that, very much like English, Arabic can use lexical repetition to build emotional force (129). They also confirm that lexical repetition is the most common form of rhetorical anaphora in Arabic, but it occurs in a denser way in rhetorical Arabic texts than in English ones (131). Jawad (2009) discusses the strategies translators tend to use in translating lexical repetition occurring in literary texts and concludes that some English-Arabic translations of literary works fall short of relaying some important stylistic aspects and eventually misrepresent the original author 
(768). Accordingly, rhetorical repetition may pose a problem for student translators despite its presence in Arabic.

Finally, tricolon is a rhetorical device achieving parallelism which has been given attention in biblical and other religious texts, but has been ignored to a large extent in English-Arabic translation studies. Morphological and syntactic parallelisms in Arabic have been stylistic features of classical Arabic since pre-Islamic times (Holes, 1995). Research on the use of parallelism in the English-Arabic-English translation of literary texts and the Quranic text has been done mainly focusing on grammatical parallelism (Mehawesh, 2013; Dror, 2016). On the other hand, Jawad (2007) discusses the translation strategies used in rendering parallelism as a textual feature in the translation of literary texts (207-8). The excerpts he presents include an example of three coordinated clauses. Tricolon per se, however, was never mentioned. The study concludes that one of the functions parallelism serves is rhetorical in addition to having organizational significance. The translated texts show that translators tend to shift the ST structures to fit the TL norms. This is a significant finding as it helps us understand how students render tricolon into Arabic. The following section provides details of the study.

\section{The study}

Given the importance and complexity of some rhetorical devices, especially the schemes, there is a noticeable paucity in studies researching translation students' ability to translate these devices from English into Arabic. Research on American presidential rhetoric and its purposes, influence and significance is available, but studies investigating the translation of US presidential rhetoric into Arabic are noticeably rare. To our knowledge, no study has so far investigated the difficulties Omani graduate translation students encounter when translating presidential speeches from English into Arabic.

Hence, the purpose of this study is to investigate to what extent Omani translation majors at the graduate level are able to identify schemes used in English political discourse and translate them properly into Arabic. Specifically, the study investigates whether students in the English Translation Master's program at Sultan Qaboos University are able to correctly render into Arabic a number of rhetorical devices used by president Obama in his first inaugural speech delivered in 2009. In addition, the research identifies and classifies student translators' problems and explains where they encounter major difficulties in their translations. The paper addresses the following: 1) the extent to which students can properly render rhetorical devices into Arabic; 2) the challenges which they encounter in translating these devices, and 3) the strategies they utilize in translating them. The results of the study are expected to help $\mathrm{EFL}$ and translation teachers in Oman and in the Arabic context to understand the nature of the problems translation graduates face when encountering rhetorical devices in political 
discourse. The research also sheds more light on the complexity of rendering some rhetorical devices used in political speeches from English into a language which is significantly different from the source language, not only linguistically, but also culturally.

\subsection{Methodology \\ 3.1.1. Participants}

The participants for this study were chosen from among the MA translation students registered for a translation course, Advanced Workshop in Translation, offered by the English Department at (SQU). 13 students who had registered in this workshop over two consecutive semesters participated in the study; 8 had enrolled in the fall semester of 2014/2015 and 5 in the fall semester of 2015/2016. At the time of the task, the students were in their penultimate semester of the program and had already taken several theoretical and practical courses in translation. They were familiar with the different types of rhetorical devices.

\subsubsection{Materials and procedures}

The translation course Advanced Workshop in Translation is required of all translation majors and is a senior class in the graduate program. In one of the course assignments, these students were asked to translate Obama's first inaugural speech. The text of the speech was given to the students as a take-home assignment.

To use as a reference point in grading the students' work, the researchers identified, highlighted and classified the most commonly and frequently used rhetorical devices used in the source text. To ensure reliability in identification and classification of these devices, the speech text was also given to two colleagues in the English Department at SQU to identify and classify the stylistic devices in the text. There was 92\% interrater reliability in the classification of the different devices used in the speech. Five commonly used rhetorical devices were chosen and identified in the text. These are the following schemes: tricolon, asyndeton, polysyndeton, anaphora and antithesis. The researchers collaboratively translated the source text focusing on the stylistic devices and gave it to two specialists in translation for verification of the translation. Following the colleagues' feedback, the researchers modified their translation incorporating the feedback and reaching a final reference translation for each instance of the rhetorical devices used in the speech.

Students were given the source text and asked to translate it assuming that at this level they will be able to identify all textual characteristics, including the stylistic devices, and produce a proper translation. Students' translations of the stylistic devices were tabulated resulting in 13 tables, one for each student. Each table contained the stylistic devices in one 
column and the student's translation in another. Then, each of the students' translations of a rhetorical device was compared to the reference translation.

\subsubsection{Data analysis and results}

Analysis of students' translation of the rhetorical devices used in Obama's speech focuses on the most frequently used schemes: tricolon, polysyndeton, asyndeton, anaphora and antithesis. The following section will focus on examining students' translation of these devices compared to the reference translation.

\subsubsection{Tricolon}

Tricolon is a rhetorical figure which repeats a textual construction three times to achieve a rhetorical effect. The repetition could be at the word, phrase, or sentence level. In the translation of tricolon, it is noticed that students were able to render some tricolon structures into Arabic without major difficulties. Careful analysis of the data indicates that, when the tricoIon structure involves simple constructions $(\mathrm{V}+\mathrm{V}+\mathrm{V}$ or $\mathrm{N}+\mathrm{N}+\mathrm{N})$, the rendition is by and large correct; however, when the structure is more complex, students tend to simplify the structure when rendering it into Arabic, instead of preserving the structure as it appears in the source text. Consider the following examples:

\section{Source text 1:}

Time and again these men and women struggled and sacrificed and worked till their hands were raw so that we might live a better life. They saw America as bigger than the sum of our individual ambitions; greater than all the differences of birth or wealth or faction (parallel verb or noun structures).

Case \#

$$
\begin{aligned}
& \text { و مرة تلو الأخرى، عانى هؤلاء الرجال و النساء وضحو ا و عملو ا حتى كلت أيديهم من أجل أن نعيش حياة أفضل. }
\end{aligned}
$$

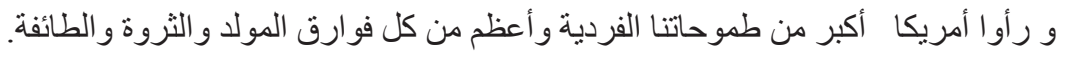

Case \#2

$$
\begin{aligned}
& \text { لقد كافح هؤلاء الرجال و النساء وضحو او عملو ا مر ارا وتكر ارا حتى كلت أيديهم حتى نعيش حياة أفضل. لقد رأوا أمريكا }
\end{aligned}
$$

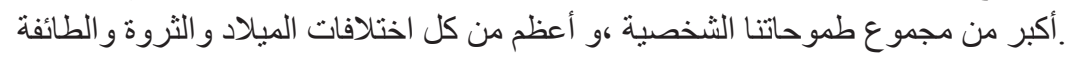

Case \#3

$$
\begin{aligned}
& \text { كافح هؤ لاء الرجال و النساء مر ارا وتكر ارا وضحو ا و عملو ا حتى نورمت أيديهم لكي نعيش نحن حياة أفضل. ور أوا أن }
\end{aligned}
$$

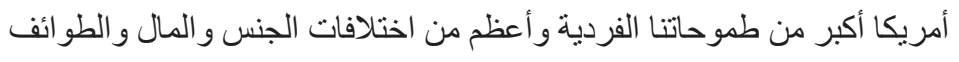


Case \#4

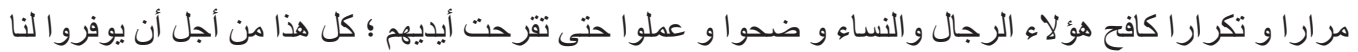

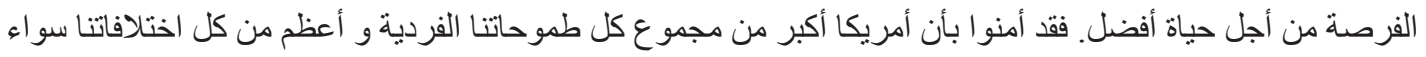
اكانت اختلافات في الأصل أو الثروة أو الانتماء

The tricolon construction in the above example is at the word level, involving the use of three coordinated verbs $(\mathrm{V}+\mathrm{V}+\mathrm{V})$ and three coordinated nouns $(\mathrm{N}+\mathrm{N}+\mathrm{N})$ at the end of the sentence. In translating these constructions, the student translators managed to preserve the rhetorical construction in English while maintaining the target language syntactic rules. In English, the structure consists of $\mathrm{S}+\mathrm{V}$ and $\mathrm{V}$ and $\mathrm{V}$. In the Arabic translation, student translators used the coordinator ' $w a$ ' (and) to connect the three parts of the tricolon construction, but moved the subject after the first verb in line with Arabic syntactic rules. This is in line with Jawad's study (2007), in which suggests that the parallel ST structures tend to be shifted to fit the TL norms. Structures like these do not seem to pose any difficulty to Arab students. However, cases which involve more complicated conjoined structures (e.g., phrases or full sentences) seem to pose a challenge to the student translators. Consider the following cases which involve adjectival phrases, partially reduced clauses, full sentences, infinitival phrases:

\section{Source text 2:}

I stand here today humbled by the task before us, grateful for the trust you have bestowed, mindful of the sacrifices borne by our ancestors (adjectival phrases).

Case \#1

$$
\begin{aligned}
& \text { أقف أمامكم اليوم يملني التو اضع لحجم المسؤولية الملقاة على عاتقي، شاكر ا لكم الثقة التي انعتم بها علي، وو اضعا } \\
& \text { نصب عيني التضحيات المقدمة من أسلافنا }
\end{aligned}
$$

Case \#2

أقف اليوم بينكم وكلي تواضع أمام ما ينتظرنا من عمل جاد، ممتنا للثقة التي أوليتموني اياها ومعترفا بالتضحيات التي بذلها أسلافنا

Case \#3

أقف هنا اليوم بتو اضع أمام المهمة التي تنتظرنا، ممتنا للثقة التي منحتموني إياها ومدركا للتضحيات التي قدمها أسلافنا.

Case \#4

اقف امامكم اليوم وانا اثتعر بالتو اضع امام المهمة التي تتنظرناو الامتنان للثقه التي منحتموني اياهاو التقدير للتضحيات التي تحملها اسلافنا

Source text 2 shows a tricolon construction with three parallel adjectival phrases. The students translators in all of the above examples have failed to preserve the rhetorical construction in their renditions, especially in the first part of the construction. They have adopted dif- 
ferent strategies to translate it. In case 1 , the student used a full sentence, starting with a verb (common in Arabic which is a predominantly vso language), followed by two adjectival phrases for the other two parts of the tricolon construction. The student in case two adopted a similar strategy, using a full nominal sentence as the first part of the construction. In the third case, the student used a prepositional phrase as the first component, followed by two adjectival phrases. The fourth case represents a dramatic shift in strategy as the student merged the three parts of the tricolon construction as part of a verbal sentence where he conjoined them as $\mathrm{N}+\mathrm{N}+\mathrm{N}$. Similarly, the situation with partially reduced parallel clauses, as shown in source text 3 , reveals even greater difficulty in rendering this type of construction, as shown below.

\section{Source text 3:}

Homes have been lost, jobs shed, businesses shuttered (partially reduced parallel clauses).

Case \#1

فقد فقدت منازل، وخسرت وظائف و اعمال

Case \#2

فالمنازل قد فقدت و الوظائف أُغلقت و التجارة كسدت

Case \#3

فقد الكثير بيوتهم، وتقلصت أعمال ووظائف و أغلقت مؤسسات تجارية

Case \#4

$$
\text { فقد الكثير مناز لهم ووظائفه و أغلقت الكثير من الأعمال التجارية }
$$

In the case of partially reduced parallel structure, such as shown in source text 3 above, the verb phrase is reduced in part two and three of the tricolon structure in order to avoid redundancy. Thus, the auxiliaries (have + been) are deleted under identity in the second and third parts of the parallel structures. Transferring this structure into Arabic, students encountered some problems trying to preserve the original structure with its rhetorical features and producing a grammatically and semantically accepted structure in Arabic. Case \# 1 shows several problems: first, the translator merged the second and third part of the tricolon structure; second, he preserved the passive structure, resulting in an unacceptable collocation (خسرت وظائف). In case \#2, the student preserved the tricolon structure but failed partially to maintain the exact passive structure in the English text, as the translator used the passive voice in the first two parts and switched to active voice in the last. In case \#3, in an attempt to preserve the full sentence structure in the first part of the English parallel structure, the student used an active voice sentence, thereby changing the passive voice in the source text. However, the translation reveals another problem, as the translator used a transitive verb in the first part of the tricolon structure, then an intransitive verb in the second and third. All of this resulted in 
a structural breach of the tricolon structure in that the first part is an active structure with a transitive verb while the third part is passive and the second part is active using an intransitive verb. In case \#4, the parallel structure of the source text is only partially preserved. The student changed the voice pattern of the whole sentence and made notable changes to the construction; the translator changed the first part into active voice, merged the first and second parts together using coordination and, finally, passivized the third part. This type of difficulty is also evident when the construction involves three full phrases, as can be seen in source text 4.

\section{Source text 4:}

...the God-given promise that all are equal, all are free, and all deserve a chance to pursue their full measure of happiness (parallel clause within one sentence).

Case \#1

$$
\text { الوعد الإلهي بأن كل الناس سواسية و أحرار و يستحقون فرصة في المطالبة بأقصى قدر من السعادة }
$$

Case \#2

$$
\text { الو عد الإلهي بأن جميعنا متساوون وجميعنا أحر ارا ونستحق جميعنا فرصة لممارسة أقصى قدر من السعادة }
$$

case \#3

$$
\text { و عد الله بأننا كلنا منساوين، كلنا أحر ارا، و الكل مستحق فرصة لكي يصل لأقصى قدر من السعادة }
$$

Case \#4

الله أر اد لنا أن نكون كلنا متساوون، كلنا أحر ارا، وكل منا يستحق أن ينال الفرصة لكي يسعى في تحقيق أكبر قدر من السعادة

Case \#5

$$
\text { ما وعدنا الله بها أن نكون كلنا سو اسية وأحر ارا، ولنا الحق بالحصول على فرصة لتحقيق أقصى قدر من السعادة }
$$

In case \# 1 above, when combining sentences in English, deletion under identity maybe applied. In Arabic, this is not possible. The full structure needs to be retained. The student combined the last two structures into one and failed to maintain the tricolon structure by combining the phrases. In case \#2, the student broke the tricolon structure by failing to maintain the correct structure when using a synonym (جميعنا) in place of (كلنا) in one of the phrases. A similar strategy is used in cases \#3 and \#4, where the translators replaced (كلنا) with (الكل). It is true that in translation training, and in writing in general, students are encouraged to avoid lexical repetition; however, the original text utilized the tricolon structure for a specific purpose, thus failing to preserve to that structure means that the intended emphasis is probably lost in translation. The student restructured the sentence and eliminated repetition completely. In case \#5, the translator failed to maintain the tricolon structure by merging the first and second phrase together, rending the second phrase as a coordinated adjectival phrase added to the complement of the first phrase. Such difficulty in the proper rendition of the tricolon con- 
struction involving three phrases is also apparent in the translation of the same construction involving three infinitival phrases, as can be seen in the translations of source text 5 below.

\section{Source text 5:}

The time has come to reaffirm our enduring spirit; to choose our better history; to carry forward that precious gift, that noble idea, passed on from generation to generation... (infinitival phrase).

Case \#1

لقد حان الوقت للتأكيد على صمود ارواحنا. لكي نختار تاريخنا الأفضل. لنمضي قدما بتلك الهدية الثمينة، تلك الفكرة النبيلة التي تنتقل من جيل إلى جيل للى على

Case \#2

لقد حان الاوان لاستعادة روحنا المتجدة ولكي نصنع تاريخا أفضل لناولكي نحمل معنا في مسيرتنا تلك الهبة العظيمة و وتلك الفكرة النبيلة الني انتقلت عبر الأجيال

Case \#3

لقد آن الأوان لنعيد إحياء روحنا الدائمة، لنختار تاريخا أفضل لنا، كي نحمل تلك الهبة الثمينة ونمضي بها قدما.

Case \#4

قد جاء الوقت لنؤكد مجددا قوة أرواحنا الجلدة. لنختار تاريخنا الأفضل. لننقل عبر الأجيال تلك الهدية القيمة

In the translation of the tricolon construction, as shown in cases \#1, \#2 and \#3, the translators failed to preserve the original meaning. They used the second part of the tricolon structure as a resultative phrase that explains the first part. This has resulted in a change in the intended message; thus, there is a semantic breach of the message intended by the tricolon structure. The same problem is evident in case \#6, where the translator used the third part of the tricolon construction to explain the second part, thus rendering an inaccurate message. While case \#4 is similar in rendition, absence of the coordinator "wa", makes the rendition less accurate as this coordinator is obligatory between coordinated items in Arabic. All these cases corroborate our initial assumption that translators, in general, encounter no difficulty when translating tricolon structures comprising simple constructions and that the difficulty arises only when they translate cases involving more complicated constructions.

\subsubsection{Polysyndeton \& asyndeton}

Both are stylistic devices which are used to join successive words, phrases or clauses; however, polysyndeton and asyndeton involve opposite structural processes and yield different functions. Whereas polysyndeton utilizes several coordinating conjunctions, asyndeton re- 
places the conjunctions with commas. Both create a completely different effect: while polysyndeton slows down the tempo or rhythm of speech and makes it moderate, asyndeton speeds up the rhythm. In English, polysyndeton structures mainly use the conjunctions and, or, but and nor. These conjunctions are even used in cases where they are not necessary; thus, polysyndeton is not the norm in Standard English, as coordinating conjunctions are usually used before the last item in a successive list of items separated by commas. Arabic, by contrast, requires the use of coordinating conjunctions between conjoined items while deletion of the conjunction is not allowed. Thus, it is predicted that translators would not encounter any difficulties in translating cases involving polysyndeton, while they might do in translating cases of asyndeton. The following examples illustrate this:

\section{Source text 1:}

Our minds are no less inventive, our goods and services no less needed than they were last week, or last month, or last year.

Case \#1

عقولنا ليست بأقل ابتكار ا، و بضائعناو خدماتتا لا تز ال مرغوبة مثل ما كانت الاسبوع الماضي أو الثهر الماضي أو السنة الماضية

Case \#2

$$
\text { عقولنا لا تقل قدرة على الابتكار، وسلعنا وخدماتنا لم يقل الطلب عليها عما كان عليه في الأسبوع الماضي أو الثهر }
$$

Case \#3

و عقولنا ليست أقل ابتكار ا، وبضائعنا وخدماتنا لا تز ال مطلوبة كما كانت الاسبوع الماضي أو الثهر الماضي أو السنة الماضية

In the above cases, the conjunctions are maintained in the target language, thus preserving the stylistic device of polysyndeton. As predicted, in all translations above, the conjunctions are transferred accurately in the $\mathrm{TL}$, and translators did not encounter any difficulty with the construction. However, in translating cases with asyndeton, students inserted conjunctions which are absent in the English source text, in order to preserve Arabic syntactic requirements. Consider the following examples:

\section{Source text 2:}

Rather, it has been the risk-takers, the doers, the makers of things...

Case \#1

$$
\text { في الو اقع، كانت رحلة المجازفين، و المنفذين، وصانعي الاشياء }
$$


Case \#2

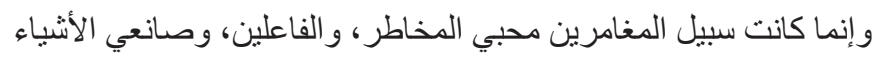

Case \#3

$$
\text { بل كانت مسيرة المغامرين و الكادحين و الصانعين }
$$

Case \#4

$$
\text { بل كانت مسيرة المغامرين المخاطرين صانعي المو اقف }
$$

Source text 2 can be interpreted in two different ways, where the three highlighted coordinated NPs (NP+NP+NP) can be understood as referring to three different nouns (risk-takers, doers, makers of things) or as one NP (risk-takers) followed by two syntactically embedded modifiers (the doers, the makers of things), meaning that the risk-takers are the doers and makers of things. In these cases, we find that the first three translators adopted the first interpretation and, thus, inserted the conjunction in all cases. This is because while English allows the deletion of the coordinating conjunction between each two coordinated items, Arabic does not allow it. So, we may assume that the students maintained the rhetorical device by using the structural patterns of the target language. In case \#4, the student adopted the second interpretation.

\subsubsection{Anaphora}

In literary criticism, anaphora is seen as a repetitive device, involving the repetition of one or more words at the start of consecutive phrases or clauses (Corbett, 1999: 390). This device is known as rhetorical anaphora used for emphasis and maintaining parallelism and unity of topic. Anaphora is often used by orators to convey and reinforce their messages. Obama relies heavily on this device in his inaugural speech to stress his points throughout different themes. The students' translations of anaphora varied from successful rendition to less successful translations. Consider the following examples:

\section{Source text 1:}

On this day, we gather ... On this day, we come ...

Case \#1

$$
\text { .... (إننا نحتشد في هذا اليوم، و إننا نجتمع لكي }
$$

Case \#2

$$
\text { (.... - إننا نحتشد في هذا اليوم ... وقد اجتمنا في هذا اليوم }
$$


Case \#3

$$
\text { .... نحن نجنمع اليوم ... ولقد جئنا في هذا اليوم }
$$

Case \#4

$$
\text { (.... - إننا نجتمع في هذا اليوم ... ولقد أتينا اليوم }
$$

In the original sentence, the prepositional phrase (on this day), functioning as an adverb of time, is topicalized because of the significance of the day itself; however, in the students' translation, we notice that all translators failed at two levels: they failed to show the anaphoric balance and, then, they relegated the anaphora to a prepositional phrase at the end of the sentence. For example, in case \#2, the translator failed to maintain the anaphoric structure by deleting the second component and, at the same time, failed to place the prepositional phrase accurately, thus failing to highlight it as is intended in the original speech. In reality, all translators failed to grasp the importance of the topicalization of the prepositional phrase. In all the above cases, the translators either failed to maintain the proper anaphoric structure, or managed to render it properly, but failed to convey the intended message as a result of not topicalizing the prepositional phrase.

\section{Source text 2:}

Our health care is too costly; our schools fail too many...

Case \#1

$$
\text { ...وارتفعت أسعار الخدمات الصحية، وفثلت مدارسنا عدة مرات }
$$

Case \#2

$$
\text { و أصبح نظام الرعاية الصحية مكلف للغاية وباءت مدارسنا بالفشل }
$$

case \#3

$$
\text { أصبح نظام الرعاية الصحية مكلّف للغاية، و انحدر مستوى المدارس }
$$

Case \#4

$$
\text { ونظامنا الصحي مكلف جدا، ونظامنا التعليمي يفتل باستمر ار }
$$

Case \#5

$$
\text { كما أن نظام رعايتنا الصحي مكلف جدا ومدارسنا تخيب آمال الكثيرين }
$$

Cases \#1, \#2 and \#3 show that the translators failed to produce the anaphoric structure. This could be due to their lack of understanding of the nature of this rhetorical device. In case \# 1 , for example, the translator did not produce the pronoun 'our' in the first part and kept it in 
the second. The anaphora is completely removed in case \#3. Only in cases \#4 and \#5 did the students realize this and produced the correct translation. This shows that, in reality, there is no difficulty in translating the text, but the translators fail to identify the rhetorical device and, therefore, fail to produce the correct translation.

\section{Source text 3:}

For us, they packed up their few worldly possessions and travelled across oceans in search of a new life. For us, they toiled in sweatshops and settled the West; endured the lash of the whip and ploughed the hard earth. For us, they fought and died...

Case \#1

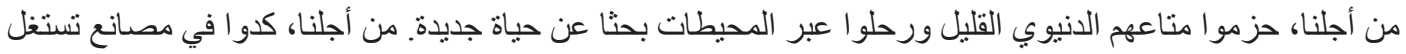

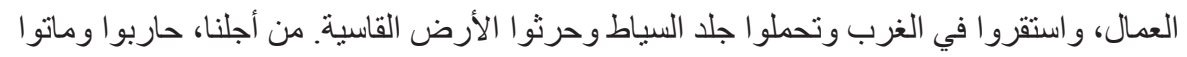

Case \#2

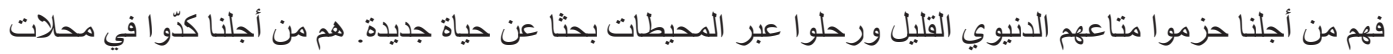

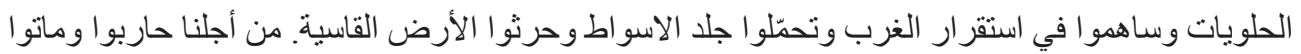

case \#3

$$
\begin{aligned}
& \text { لأجلنا، طوى هؤ لاء ما بملكون في هذه الدنباوجابوا البحار بحثا عن حياة جديدة، ولأجلنا كدحوا في عملهم الثناق وأرسوا }
\end{aligned}
$$

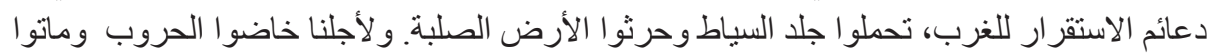

\section{Case \#4}

فلأجلنا حملوا القليل من ممتلكاتهم الدنيوية وارتحلو ا عبر المحيطات بحثاً عن حياة جديدة ، و ولأجلنا كدحو ا في أماكن العمل

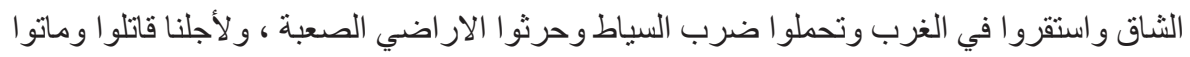

The anaphoric structure in the source text is a very common construct in the target language and is evidently easily identifiable; therefore, the translators did not have any problem in providing the proper rendition of the text. They maintained the exact anaphoric structure at the beginning of each phrase in Arabic. This is also evident in the next example.

\section{Source text 4:}

This is the price and the promise of citizenship. This is the source of our confidence - the knowledge that God calls on us to shape an uncertain destiny. This is the meaning of our liberty and our creed...

Case \#1

$$
\text { هذا هو الثنم، هذا هو و عد المو اطنة.و هذا هو مصدر ثقتنا؛ علمنا بأن الله يدعونا للمشاركة في تحديد هذه المصائر }
$$


Case \#2

$$
\text { هذا هو الثمن و هذا هو و عد المو اطنية. هذا هو مصدر إيماننا، معرفة أن الله يدعونا أن نرسم مصيرا غير مؤكد. هذا هو }
$$

Case \#3

$$
\text { هريتا هو ثمن الوطنية وو عدها. هذا هو مصدر ثقتناـ معرفتنا بأن الله يدعونا بأن نصوغ مصيرا غير مؤكد. هذا هو معنى }
$$

Case \#4

$$
\text { هذا هو الثمن و هذا هو و عد المو اطنة. كما أن هذا هو مصدر إيماننا بمعرفتنا أن الله أوكل إلينا مهمة تحديد المصائر }
$$

Since the equivalent anaphoric structures for (for us, this is the...) (لأجلنا، هذا هو الـ are commonly used in the target language, the majority of translators did not have any apparent problem in identifying and rendering them correctly.

\subsubsection{Antithesis}

Antithesis is a parallel structure and is used mainly to highlight contrast. Wales (2014: 25) explains that antithesis "effectively contrasts ideas by contrasting lexical items in a formal structure of parallelism". This device is usually used to highlight contrasts and make them more memorable. Consider these examples and their translations:

\section{Source text 1:}

To those leaders around the globe who seek to sow conflict, or blame their society's ills on the West - know that your people will judge you on what you can build, not what you destroy.

\section{Case \#1}

فليعلم أولئك القادة الذين يبحثٔون عن نشر الصر اع أو يلقون اللوم على الغرب فيما ينعلق بسلبيات مجتمعاتهم أن شعوبهم

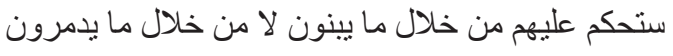

\section{Case \#2}

و لأولئك القادة حول العالم الذين يسعون لزرع النزاع و الذين بلومون الغرب على أمر اض مجتمعاتهم فأننا نقول لهم بأن

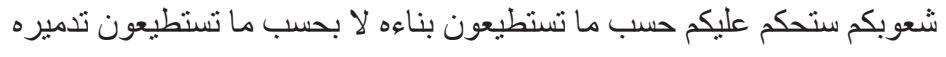

\section{Case \#3}

و لأولئك القادة حول العالم الذين يسعون لزرع النزاع و الذين بلومون الغرب على أمر اض مجتمعاتهم فأننا نقول لهم بأن شعوبكم ستحكم عليكم حسب ما تسنطيعون بناءه لا بحسب ما لـا تستطيعون تدميره 
Case \#4

$$
\begin{aligned}
& \text { ولكل القادة حول العالم الذين يسعون إلى غرس بذور الخلافات أو يُحمِّلون الغرب مشكلات مجتمعاتهم أقول لهم: أعلموا }
\end{aligned}
$$

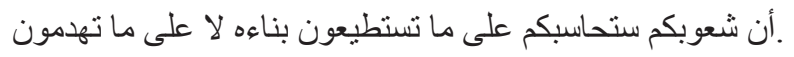

In most cases, the translators maintained the contrast which is involved in antithesis, as in cases \#1, \#2 and \#3. However, in some cases, such as \#4, the students failed to maintain the parallel structure which is a very important component of antithesis. In general, antithesis as a rhetorical device is very common in Arabic discourse. Therefore, translators do not seem to have any evident difficulty rendering it properly, though they sometimes may have an issue with the parallel component contained within antithesis. This is apparent in the next example:

\section{Source text 2:}

The success of our economy has always depended not just on the size of our Gross Domestic Product, but on the reach of our prosperity.

Case \#1

إن نجاح اقتصادنا لم يعتمد دائما على مجرد حجم إجمالي إنتاجنا المحلي وحسب بل و على مدى انتشار رخائنا.

Case \#2

$$
\text { إن نجاح اقتصادنا لم يعتمد دائما على مجرد حجم إجمالي إنتاجنا المحلي وحسب بل و على مستويات الرخاء. }
$$

Case \#3

$$
\begin{aligned}
& \text { فنجاح اقتصادنا لا يعتمد دائما على حجم الناتج المحلي الإجمالي فحسب و إنما يعتمد على نجاحنا في العمل من أجل إلى إلى } \\
& \text { الوصول إلى مستويات الرخاء والازدهار. }
\end{aligned}
$$

All these examples show that antithesis, in general, does not pose a serious challenge to translators as they have overall succeeded in maintaining antithesis and preserving the intended rhetorical function. This is due to the commonality of the structure in the target language.

\section{Conclusion}

Rhetorical devices are frequently manipulated in political speeches to strike a balance between the obvious and obscure (Corbett, 1999), to add an aesthetic element to the speech, and to achieve a multitude of communicative functions, such as increasing the audiences' emotional involvement and their acceptance of the arguments delivered within the speech. Data analysis of the translations produced by the students shows that many of the rhetorical devices used in Obama's speech were kept intact in the target text, while others were missed entirely or modified to suit the linguistic patterns and references of the target language. Translators 
adopted different strategies, such as rewriting, reorganizing, adding and deleting, with varying degrees of success. In many cases, such strategies have led to the distortion of rhetorical devices in both form and function. Furthermore, analyses of translators' renditions into the target language reveal that the translators' lack of awareness of the rhetorical devices used in the speech also led to a failure in reproducing the intended effect or the original message.

In translating rhetorical devices, the structure is an important factor, as is shown in the analysis of tricolon, where simple tricolon structures were noticeably easier to render into the target language than more complex ones. In these cases, the translators failed to produce parallel structures equivalent to those used in the source text and, in many cases, merged two parts together, thus eliminating the tricolon structure. In some other cases, the tricolon structures were weakened by changing voice and transitivity, thus eliminating parallelism, which is an essential component in tricolon structures. The dismissal of parallelism in a number of translation cases is a strong indicator that second language training may have led to a misrepresentation of this rhetorical device. EFL students are taught to avoid repetitive structures to improve their quality of writing; therefore, it is not surprising that, in translating tricolon structures, students merged two or more parts of the tricolon structure to avoid repetition.

In the translation of polysyndeton, the translators, as predicted, did not encounter any difficulty in translating cases involving polysyndeton, because the structural norm in Arabic is to use coordinators between each two coordinated elements. On the other hand, in translating cases involving asyndeton they tended to insert the coordinators between two conjoined elements, which is in line with Arabic writing patterns. This has resulted in changing asyndeton constructions into polysyndeton, thus eliminating its intended rhetorical effect.

As to anaphora, it is found that when this device involves a minimal structure, such as a pronoun, translators seem to overlook it and as a result have failed to render it correctly; however, when the anaphora involves a highly identifiable structure, they do not seem to face any noticeable difficulty in rendering the anaphora correctly in the target language.

Overall, it is found that, when the schemes, such as antithesis, is common in the target language, the translators generally do not encounter any apparent difficulty in rendering it properly. It is noticed that, in many cases, as the translator tried to keep the source text forms and structure intact, they produced unacceptable lexical combinations or collocations in target language. They also showed a tendency to break up structural patterns, especially in translating tricolon structures.

Stylistic and rhetorical devices are functionally, communicatively and semantically important. Translators, therefore, must recognize their importance and need to identify them correctly in the source text, before embarking on the actual act of translation. This will help them render these devices properly and maintain the intended message and effects of the source text. 


\section{Works cited}

Abdellah, Antar Solhy, 2007: "CDELT Occasional Papers Ain Shams University", [available at http://www.svu.edu.eg/faculties/education/cv/manaheg/antarreasearch/research/eng/ Error\%20analysis\%20\&translating\%20Arabic\%20anaphora/English\%20Major's\%20errors\%20 in\%20endophora.pdf, date of consultation: October 10th, 2016].

Abdul-Raof, Hussein, 2001: Arabic Stylistics: A Coursebook, Wiesbaden: Otto Harrassowitz Verlag. Abdul-Raof, Hussein, 2006: Arabic Rhetoric: A Pragmatic Analysis, New York, NY: Routledge.

Al-Ameed, Riyadh Tariq Kadhim, 2015: "A Pragmatic Study of Barak Obama's Political Propaganda”, Journal of Education and Practice 6 (20), 75-86.

AL-HAQ, Fawwaz Al-Abed, 1992: "Functional or Anaphoric Control in Jordanian Arabic?", Language Sciences 14,1-28.

Al-Mashkoor, Haitham Ghazi, 2014: "The Significance of Teaching Anaphora in Translation”, Journal of University of Thi-Qar 9 (3), 1-9.

Al-Sabbagh, Rania, \& Khaled Elghamry, 2007: "Arabic Anaphora Resolution: A Distributional, Monolingual and Bilingual Approach" in Proceedings of the Information and Communication Technologies International Symposium (ICTIS'07) [available at http://al-sabbaghrania.synthasite. com/resources/Microsoft\%20Word\%20-\%20Arabic_Anaphora_Resolution\%5B1\%5D.pdf, date of consultation: October 5th, 2016].

Beeston, A. F. L., 1983: Arabic Literature to the End of the Umayyad Period, Cambridge: Cambridge University Press.

Corbett, E. P. J., 1999: Classical rhetoric for the modern student 4th ed., New York, NY: Oxford University Press.

Dickins, James, Sándor Hervey \& Ian HIgGIns, 2002: Thinking Arabic Translation: A Course in Translation Method: Arabic to English, New York, NY: Routledge.

DroR, Yehudit, 2016: “Grammatical Parallelism in the Qur'an”, International Journal of Cognitive and Language Sciences 3 (6), 459.

GEARY, James, 2011: I is an Other: The secret life of metaphor and how it shapes the way we see the world, New York, NY: Harper Collins.

Hernandez-Guerra, Concepción, 2012: "Outstanding Rhetorical Devices and Textuality in Obama's Speech in Ghana, Africa", Open Journal of Modern Linguistics 2 (3), 97-104.

Holes, Clive, 1995: "The Structure and Function of Parallelism and Repetition in Spoken Arabic: A Sociolinguistic Study”, Journal of Semitic Studies XL (1), 57-81. 
IbRĀHĪm, Zaynab, Sabiha T. Aydelott \& Nagwa Kassabgy (eds.), 2000: Diversity in Language: Contrastive Studies in Arabic and English Theoretical and Applied Linguistics, Cairo: American University in Cairo Press.

JAWAD, Hisham A., 2007: "Paraphrase, parallelism and chiasmus in Literary Arabic: Norms and translation strategies”, Babel 53 (3), 196-215.

JAWAD, Hisham A., 2009: "Repetition in Literary Arabic: Foregrounding, Backgrounding, and Translation Strategies", Meta: Journal des traducteurs / Meta: Translators' Journal 54 (4), 753769.

Johnstone, Barbara, 1987: "Parataxis in Arabic: Modification as a model for persuasion", Studies in Language 11 (1), 85-98.

Khalı, Ghusoon Subhi, 2011: "Parataxis, Hypotaxis, Style, and Translation”, Mujalat Kulliat Altarbyyah Al-asasieh 68, 9-17.

MarzARI, Robert, 2006: Arabic in Chains: Structural Problems and Artificial Barriers, Berlin: Hans Schiler.

MeHAWESH, Mohammad, 2013: "Grammatical Parallelism in the Translation of Advertising Texts with Particular Reference to English and Arabic", Asian Social Science 9 (10), 254-263.

Meisamı, Julie Scott, \& Paul Starkey (eds.), 1998: Encyclopedia of Arabic Literature, Volume 2, New York: NY: Routledge.

RusselL, Robert A., 1984: "Historical Aspects of Subject-Verb Agreement in Arabic", Proceedings of the first Eastern States Conference on Linguistics, 116-127. [available at http://www.public. asu.edu/ gelderen/Russell1984.pdf, date of consultation: October 12th, 2016].

Semino, Elena, 2008: Metaphor in Discourse, Cambridge: Cambridge University Press.

WaLES, Katie, 2014: A Dictionary of Stylistics, 3rd ed., New York: Routledge. 